\title{
Kualitas Pelayanan dan Kepuasan Pelanggan Terhadap Loyalitas Pelanggan DANA pada masa Physical Distancing
}

\author{
Muhammad Rinov Cuhanazriansyah ${ }^{1}$, Muhammad Giatman ${ }^{2}$, Ernawati $^{3}$ \\ 1,2,3 Universitas Negeri Padang, Padang, Indonesia
}

\begin{abstract}
Keywords:
Quality;

Satisfaction;

Customer

Loyalty

\section{ABSTRACT}

Abstract: The government imposes social restrictions or conditions for maintaining distance to prevent the transmission of the corona virus 19 . The purpose of this study was to analyze service quality and customer satisfaction on DANA customer loyalty during the physical distancing period. This research uses quantitative research methods. The data used in this study is primary data. Data collection techniques by distributing questionnaires and asking respondents to fill out the questionnaire. Each variable in the questionnaire was measured using a Likert scale from a scale of 1 to 5 . The non-probability sampling method was used in selecting a sample consisting of 120 respondents using DANA. The data analysis technique used multiple linear regression quantitative analysis. The result of the research is the regression coefficient value of 0.470 , which means that every increase in service quality has an effect on increasing Customer Loyalty by 0.470 . In addition, the significance value of the Service Quality variable of $=0.000<0.05$ indicates that service quality has a positive effect on customer loyalty. Customer Satisfaction has a positive effect on Customer Loyalty. This is indicated by the regression coefficient value of Customer Satisfaction of 0.513 and the significance value of the Customer Satisfaction variable of 0.000 which is smaller than the acceptable significant value of $0.05(\alpha=0.000<0.05)$ so that customer satisfaction has a positive effect on customer loyalty. So the quality of service and service satisfaction have a positive influence on loyalty.
\end{abstract}

Abstrak: Pemerintah memberlakukan adanya pembatasan social atau kondisi menjaga jarak untuk mencegah penularan virus corona 19. Tujuan penelitian ini untuk menganalisis kualitas pelayanan dan kepuasan pelanggan terhadap loyalitas pelanggan DANA pada masa physical distancing. Penelitian ini menggunakan metode penelitian kuantitatif. Data yang digunakan dalam penelitian ini adalah data primer. Teknik pengumpulan data dengan cara menyebarkan kuesioner dan meminta responden untuk mengisi kuesioner tersebut. Setiap variabel dalam kuesioner diukur dengan menggunakan skala likert dari skala 1 sampai dengan skala 5 . Metode nonprobability sampling digunakan dalam melakukan pemilihan sampel yang terdiri dari 120 responden pengguna DANA. Teknik analisis data menggunakan analisis kuantitatif regresi linier ganda. Hail penelitian nilai koefisien regresi sebesar 0,470 yang berarti bahwa setiap kenaikan kualitas pelayanan berpengaruh terhadap meningkatnya Loyalitas Pelanggan sebesar 0,470. Selain itu nilai signfikansi variabel Kualitas Pelayanan sebesar $\alpha=0,000<0,05$ mengindikasikan bahwa kualitas pelayanan berpengaruh positif terhadap loyalitas pelanggan. Kepuasan Pelanggan berpengaruh positif terhadap Loyalitas Pelanggan. Hal ini ditunjukkan dengan nilai koefisien regresi Kepuasan Pelanggan sebesar 0,513 dan nilai signifikanasi variabel Kepuasan Pelanggan sebesar 0,000 lebih kecil dibandingkan dengan nilai signifikan yang dapat diterima yaitu 0,05 $(\alpha=0,000<0,05)$ sehingga kepuasan pelanggan berpengaruh positif terhadap loyalitas pelanggan. Maka kualitas pelayanan dan kepuasaan pelayanan memberikan pengaruh positif terhdap loyalitas.

$\begin{array}{ll}\text { History: } & \\ \text { Received } & \text { : 02 Mei } 2021 \\ \text { Revised } & \text { : 03 Mei } 2021 \\ \text { Accepted } & \text { : 22 Juni } 2021 \\ \text { Published } & \text { : 25 Juli } 2021\end{array}$

Publisher: Undiksha Press

Licensed: This work is licensed under a Creative Commons Attribution 3.0 License

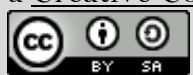




\section{Pendahuluan}

Perkembangan uang elektronik di Indonesia semakin pesat seiring dengan perkembangan teknologi internet dan kemudahan penggunaan media telepon (smart ponsel). Perkembangan teknologi menumbuhkan transformasi alat pembayaran untuk memudahkan transaksi agar dapat dilakukan secara efektif dan efisien(Pebriana, 2017; Yulianty \& Mauludy, 2019). Banyak perusahaan yang bergerak dibidang informasi teknologi dan jasa keuangan menawarkan berbagai kemudahan bertransaksi secara non tunai/ elektronik (Ishak, 2017). Bentuk dari alat pembayaran tersebut dapat berupa chip atau server, contoh dari bentuk uang elektronik antara lain : e-money, e-wallet dII (F. K. Dewi \& Ariyanti, 2020; Sisca Aulia, 2020). Uang elektronik yang berdasarkan aplikasi ponsel/ handphone contohnya ada Gopay kepunyaan gojek, T-Cash kepunyaan telkomsel, DANA kepunyaan Lippo Grup dll. Salah satu bentuk uang elektronik yang berbasis server adalah DANA. DANA merupakan aplikasi dari uang elektronik yang memberi kesempatan dan kemudahan dalam melakukan transaksi dan menawarkan juga berbagai point dan diskon (F. K. Dewi \& Ariyanti, 2020; Ishak, 2017; Suwandi et al., 2019). Sampai tahun 2018 diperkirakan pengguna DANA di Indonesia mencapai 9,5 juta pengguna. Rata - rata pengguna uang elektronik berupa DANA adalah anak muda jaman now/ kekinian dan memiliki gaya hidup yang modern dan konsumtif (F. K. Dewi \& Ariyanti, 2020). DANA adalah aplikasi smart yang memberikan kemudahan pembayaran dalam transaksi yang dilakukan secara online. Kemudahan yang didapat dari penggunaan DANA ini adalah selain memudahkan dalam melakukan transaksi pembayaran secara elektronik juga sebagai sarana mendapatkan kemudahan dalam pembayaran.

Pandemi COVID-19 ini menyebabkan di Indonesia menerapkan adanya kondisi physical distancing. Pemerintah memberlakukan adanya pembatasan social atau kondisi menjaga jarak untuk mencegah penularan virus corona 19 (Hendriyati \& Santoso, 2021; Pakpahan, 2020; Putri, 2020). Masyarakat dihimbau untuk menghindari adanya kerumunan, keluar rumah maupun beraktivitas yang melibatkan banyak pihak/orang. Semua aktivitas dan kegiatan disarankan dilakukan melalui rumah saja sehinggan muncullah istilah WFH (Work From Home) (Chang et al., 2020; Darmalaksana et al., 2020; Nurkholis, 2020). Penerapan kondisi physical distancing mengakibatkan penggunaan internet semakin pesat untuk aktivitas pekerjaan, belajar atau kegiatan lainnya. Dengan melakukan aktivitas dirumah diharapkan dapat memutuskan penyebaran COVID-19, oleh karena itu masyarakat dihimbau untuk dirumah saja (Nalini, 2021; Pakpahan, 2020). Guna memenuhi kebutuhan hidupnya masyarakat menggunakan internet. Salah satunya adalah dengan memilih berbelanja online baik untuk memenuhi kebutuhan makanan, perlengkapan rumah maupun kebutuhan lainnya. Dalam segi pembayarannya pun tidak perlu harus memberikan uang tunai, tidak harus bertemu, tidak harus datang. Perkembangan teknologi menumbuhkan transformasi alat pembayaran untuk memudahkan transaksi agar dapat dilakukan secara efektif dan efisien. Banyaknya perusahaan yang bergerak dibidang informasi teknologi dan jasa keuangan menawarkan berbagai kemudahan bertransaksi secara non tunai/ elektronik. Salah satu bentuk uang elektronik yang berbasis server adalah DANA.

Loyalitas pelanggan merupakan hal yang sangat penting bagi perusahan di era kompetisi bisnis yang semakin ketat seperti saat ini (Annas et al., 2019; Situmorang, 2017). Pentingnya loyalitas pelanggan bagi perusahaan sudah tidak diragukan lagi, banyak perusahaan sangat berharap dapat mempertahankan pelanggannya dalam jangka panjang, bahkan jika mungkin untuk selamanya (Annas et al., 2019; Jalil et al., 2017). Perusahaan yang mampu mengembangkan dan mempertahankan loyalitas konsumen akan memperoleh kesuksesan jangka panjang. Loyalitas pelanggan akan terbentuk saat konsumen sudah mendapatkan kepuasan terhadap produk yang dihasilkan oleh sebuah usaha/industry (Jalil et al., 2017; Nuraeni et al., 2020). Kualitas pelayanan akan menjadi indicator dalam meningkatkan kepuasan seorang pelanggan. Jika kualitas yang diberikan sesuai dengan harapan pelanggan maka pelanggan akan setia atau loyal terhadap produk yang dihasilkan(Bulan, 2016; Saripudin et al., 2021). Sebuah usaha akan tetap eksis dan sukses dengan para pesaing jika dapat menciptakan sebuah produk yang baik, berkualitas dan terjangkau oleh masyarakat. Untuk memenuhi kondisi tersebut maka perusahaan harus memahami perilaku konsumen, apa yang di inginkan konsumen dan yang dapat memberikan kepuasan terhadap 
konsumen yang bersangkutan (Jalil et al., 2017; Mulyati Akib, Ika Maya Sari, 2017). Kenyamanan, kualitas dan terpenuhinya keinginan dan harapan pelanggan menjadi tujuan utama dari para pelaku usaha industry. Untuk menciptakan kualitas pelayanan yang baik dibutuhkan strategi pemasaran yang baik juga. Jenis usaha harus dapat menawarkan pelayanan yang dapat diterima dan dirasakan oleh pelanggan sesuai atau bahkan dapat melebihi apa yang diharapkan atau ekspektasi dari para pelanggan. Semakin tinggi tingkat kualitas produk yang ditawarkan dan dapat dirasakan lebih dari harapan nya maka pelanggan akan merasa puas.

Salah satu factor yang menjadikan masyarakat mempercayakan pemenuhan kebutuhan hidupnya secara online karena adanya kualitas pelayanan yang ditawarkan, dan kepuasan yang didapatkan. Jika kedua hal tersebut terpenuhi maka dengan sendirinya loyalitas dari masyarakat / konsumen akan terbentuk dengan sendirinya. Terkait dengan kondisi physical distancing inilah masyarakat akhirnya memilih menggunakan media online untuk memenuhi kebutuhan hidupnya. Temuan ini sejalan dengan penelitian terkait kualitas pelayanan dan kepuasan pelanggan terhadap loyalitas pelanggan. Kualitas pelayanan, fasilitas dan persepsi harga secara simultan berpengaruh positif dan signifikan terhadap kepuasan konsumen (Haryoko et al., 2020; Setiawati et al., 2019). Temuan lain juga menyatakan loyalitas pelanggan dipengaruhi oleh kualitas pelayanan (Anggia et al., 2015; Bulan, 2016). Perbedaan penelitian ini dengan sebelumnya terkait dengan variable yang digunakan, selain itu penelitian ini dilakukan pada masa pandemic covid-19 pada salah satu aplikasi DANA. Adanya penelitian ini diharapkan dapat meningkatkan loyalitas pelanggan dalam menggunakan aplikasi data dimasa pandemic Covid-19. Tujuan penelitian ini untuk menganalisis kualitas pelayanan dan kepuasan pelanggan terhadap loyalitas pelanggan dana pada masa physical distancing.

\section{Metode}

Penelitian ini menggunakan metode penelitian kuantitatif. Data yang digunakan dalam penelitian ini adalah data primer. Teknik pengumpulan data dengan cara menyebarkan kuesioner dan meminta responden untuk mengisi kuesioner tersebut. Setiap variabel dalam kuesioner diukur dengan menggunakan skala likert dari skala 1 sampai dengan skala 5. Metode non-probability sampling digunakan dalam melakukan pemilihan sampel yang terdiri dari 120 responden pengguna DANA. Terdapat dua variabel yang digunakan dalam penelitian ini, yaitu variabel $Y$ dan variabel $X$. Variabel $Y$ merupakan variabel dependen atau variabel terikat. Pada penelitian ini variabel loyalitas pelanggan merupakan variabel $\mathrm{Y}$. Variabel $\mathrm{X}$ merupakan variabel independen atau variabel bebas. Pada penelitian ini variabel kualitas pelayanan sebagai variable $\mathrm{X} 1$ dan kepuasan pelanggan sebagai variabel X2. Penelitian ini menggunakan analisis faktor dari program SPSS 24 untuk menguji validitas. Pengujian reliabilitas menggunakan program SPSS 24 untuk menghitung cronbach's alpha. Setelah melakukan pengujian validitas dan reliabilitas, peneliti menguji hipotesis dengan menggunakan program SPSS 24 . Setelah melakukan uji validitas dan reliabilitas, peneliti melakukan pengujian hipotesis dengan menggunakan analisis regresi linier berganda pada program SPSS 24.

\section{Hasil dan Pembahasan}

\section{Hasil Penelitian}

Penelitian ini dilakukan terhadap 100 responden dengan tingkat respons $100 \%$. Tabel di bawah ini menggambarkan responden berdasarkan jenis kelamin. Tabel tersebut menunjukkan terdapat $63 \%$ responden wanita dan $37 \%$ responden pria. Responden perempuan lebih tertarik menggunakan DANA sebagai alat pembayaran pada masa physical distancing dibandingkan dengan laki-laki. Analisis selanjutnya menjelaskan deskripsi responden berdasarkan usia, yang terlihat pada tabel 2. Usia responden yang paling jelas adalah berkisar antara 20 hingga 25 tahun yaitu dalam persentase $45 \%$ dan periode 25 hingga 30 tahun pada tingkat 55\%. Usia tersebut termasuk dalam kategori mahasiswa dan pekerja. 
Tabel 1. Deskripsi Responden berdasarkan Jenis Kelamin.

\begin{tabular}{lcccc}
\hline & Frequenc $y$ & Percent age & $\begin{array}{l}\text { Valid } \\
\text { Percen tage }\end{array}$ & Cumulative Percentage \\
\hline $\begin{array}{l}\text { Valid Male } \\
\text { Female Total }\end{array}$ & 37 & 37,0 & 37,0 & 37,0 \\
& 63 & 63,0 & 63,0 & 63,0 \\
& 100 & 100,0 & 100,0 & \\
\hline
\end{tabular}

Tabel 2. Deskripsi Responden berdasarkan Usia.

\begin{tabular}{lcccc}
\hline & Frequen cy & Percenta ge & $\begin{array}{l}\text { Valid } \\
\text { Percen tage }\end{array}$ & Cumulative Percentage \\
\hline $\begin{array}{l}\text { Valid } \\
20-25 \\
\text { years old }\end{array}$ & 45 & 45,0 & & \\
$\begin{array}{l}25-30 \\
\text { years old }\end{array}$ & 55 & 55,0 & 55,0 & 45,0 \\
& 100 & $\mathbf{1 0 0 . 0}$ & $\mathbf{1 0 0 . 0}$ & $\mathbf{1 0 0}$ \\
\hline Total & $\mathbf{1 0 0}$ & & & 55,0 \\
\hline
\end{tabular}

Tabel 3. Deskripsi Responden Berdasarkan Pekerjaan.

\begin{tabular}{lllll}
\hline & Freque ncy & Percent age & Valid Percent age & Cumulative Percentage \\
\hline $\begin{array}{l}\text { Valid } \\
\text { student }\end{array}$ & 15 & 15,0 & 15,0 & 15,0 \\
employee & 32 & 32,0 & 32,0 & 47,0 \\
entrepreneur & 31 & 31,0 & 31,0 & 78,0 \\
others & 22 & 22,0 & 22,0 & 100,0 \\
& $\mathbf{1 0 0}$ & $\mathbf{1 0 0 . 0}$ & $\mathbf{1 0 0 . 0}$ & \\
\hline Total & & &
\end{tabular}

Hasil Uji Validitas menggunakan SPSS, pengujian validitas ini bertujuan untuk mengetahui kelayakan poin-poin pertanyaan, pernyataan, dan indikator dalam menggambarkan variabel tertentu. Hasil perhitungan $r$ dibandingkan dengan $r$ tabel, di mana $d f=n-2$ dengan signifikansi $5 \%$. Jika $r$ tabel $<r$ perhitungan, ini menunjukkan bahwa indikator tersebut valid.

Tabel 4. Hasil Uji Validitas.

\begin{tabular}{|c|c|c|c|}
\hline No. & Constructs & Factor Loading & Status \\
\hline \multirow[t]{6}{*}{1.} & Kualitas Pelayanan & & \\
\hline & $-\quad \mathrm{KP1}$ & 0,75 & Valid Valid \\
\hline & $-\quad \mathrm{KP} 2$ & 0,83 & Valid Valid \\
\hline & $-\quad K P 3$ & 0,79 & Valid Valid \\
\hline & - KP4 & 0,80 & \\
\hline & $-\quad \mathrm{KP5}$ & 0,82 & \\
\hline \multirow[t]{5}{*}{2.} & Kepuasan Pelanggan & & \\
\hline & - KPE1 & 0,76 & Valid Valid \\
\hline & - KPE2 & 0,75 & Valid Valid \\
\hline & - KPE3 & 0,82 & \\
\hline & - KPE4 & 0,73 & \\
\hline
\end{tabular}




\begin{tabular}{|c|c|c|c|}
\hline No. & Constructs & Factor Loading & Status \\
\hline \multirow[t]{6}{*}{3.} & Loyalitas Pelanggan & & \\
\hline & - $\quad$ LP1 & 0,72 & Valid \\
\hline & - $\quad$ LP2 & 0,74 & Valid Valid \\
\hline & - LP3 & 0,70 & Valid Valid \\
\hline & $-\quad$ LP4 & 0,72 & \\
\hline & - LP5 & 0,80 & \\
\hline
\end{tabular}

Berdasarkan tabel 4 diatas menunjukkan seluruh pernyataan valid, karena $r$ tabel $<r$ perhitungan. Selanjutnya dilakukan uji reliabilitas. Reliabilitas adalah ketergantungan yang memanifestasikan stabilitas dan konsistensi responden dalam menjawab poin-poin pertanyaan atau indikator. Untuk selanjutnya, dapat menjelaskan konstruk penelitian, Alpha> 0,60 dianggap dapat diandalkan.

Tabel 5. Hasil Uji Reliabilitas

\begin{tabular}{lll}
\hline Variabel & Cronbach alpha & Category \\
\hline Kualitas Pelayanan & 0,815 & Reliable \\
Kepuasan Pelanggan & 0,673 & Reliable \\
Loyalitas Pelanggan & 0,815 & Reliable \\
\hline
\end{tabular}

Berdasarkan hasil analisis nilai yang diperoleh variable kualitas pelayanan 0,815 , kepuasan 0,673 , dan loyalitas pelanggan 0,815 . Nilai tersebut menunjukankan nilai alpha $>0,60$ pada seluruh variable menunjukan reliabilitas tinggi. Selanjutnya dilakukan uji regresi, regresi memiliki tujuan untuk menguji dampak dari satu variabel ke variabel lain. Penelitian ini menggunakan uji regresi linier berganda karena untuk mengetahui pengaruh dari lebih dari satu variabel independen (variabel $\mathrm{X}$ ) terhadap satu variabel dependen (variabel Y).

Tabel 6. Model Summary

\begin{tabular}{ccccc}
\hline Model & R & R Square & Adjusted R Square & Std. Error of the Estimate \\
\hline 1 & 0,553 & 0,305 & 0,294 & 3,164 \\
\hline
\end{tabular}

Tabel 7. Uji ANOVA

\begin{tabular}{lllllll}
\hline Model & & Sum of Squares & Df & Mean Square & F & Sig. \\
\hline 1 & Regression & 532,513 & 2 & 266,256 & 26,604 &, $000^{b}$ \\
& Residual & 1210,971 & 121 & 10,008 & & \\
& Total & 1743,484 & 123 & & & \\
\hline
\end{tabular}

Tabel 8. Hasil Uji Regresi menggunakan SPSS

\begin{tabular}{llccccc}
\hline \multirow{2}{*}{ Model } & \multicolumn{2}{c}{$\begin{array}{c}\text { Unstandardized } \\
\text { Coefficients }\end{array}$} & $\begin{array}{c}\text { Standardized } \\
\text { Coefficients }\end{array}$ & \multirow{2}{*}{ T } & Sig. \\
\cline { 3 - 5 } & & B & Std. Error & Beta & & \\
\hline 1 & (Constant) & $-0,818$ & 2,458 & & $-0,333$ & 0,740 \\
& Kualitas Pelayanan & 0,470 & 0,123 & 0,328 & 3,810 & 0,000 \\
& Kepuasan Pelanggan & 0,513 & 0,141 & 0,315 & 3,650 & 0,000 \\
\hline
\end{tabular}

Berdasarkan tabel diatas maka dapat digunakan rumus persamaan regresi linear berganda pada penelitian ini, yaitu: $Y=-0,818+0,470 X 1+0,513 X 2$. tabel ANOVA di atas, dapat terlihat nilai $F$ hitung sebesar 26,604 dengan nilai signifikansi sebesar 0,000. Hal tersebut menunjukkan bahwa nilai signfikansi lebih kecil dibandingkan dengan standar nilai signifikansi $0,000<0,005$, sehingga kualitas pelayanan dan kepuasan pelanggan secara simultan atau bersama-sama memiliki pengaruh positif 
terhadap loyalitas pelanggan. Berikutnya untuk mengetahui seberapa besar pengaruh kualitas pelayanan dan kepuasan pelanggan secara simultan terhadap loyalitas pelanggan dapat melihat nilai koefisien determinasi pada kolom R square. Pada kolom R square, terlihat nilai koefisien determinasi sebesar 0,305 , hal tersebut berarti $30,5 \%$ variabel loyalitas pelanggan dapat dijelaskan oleh variabel kualitas pelayanan dan kepuasan pelanggan, sedangkan $69,5 \%$ sisanya dipengaruhi oleh variabel lain.

Berdasarkan hasil analisis pengujian hipotesis diatas, maka dapat terlihat bahwa hipotesis pertama diterima yaitu Kualitas Pelayanan berpengaruh positif terhadap Loyalitas Pelanggan. Hal tersebut ditunjukkan oleh nilai koefisien regresi sebesar 0,470 yang berarti bahwa setiap kenaikan Kualitas Pelayanan sebesar 1 akan berpengaruh terhadap meningkatnya Loyalitas Pelanggan sebesar 0,470 . Selain itu didukung juga dengan nilai signfikansi variabel Kualitas Pelayanan sebesar 0,000 lebih kecil dibandingkan nilai signfikan yang dapat diterima $0,05 \quad(\alpha=0,000<0,05)$ mengindikasikan bahwa Kualitas Pelayanan berpengaruh positif terhadap Loyalitas Pelanggan. Pada pengujian hipotesis, hipotesis kedua juga diterima yaitu Kepuasan Pelanggan berpengaruh positif terhadap Loyalitas Pelanggan. Hal ini ditunjukkan dengan nilai koefisien regresi Kepuasan Pelanggan sebesar 0,513 yang berarti bahwa setiap kenaikan Kepuasan Pelanggan sebesar 1 akan berpengaruh terhadap meningkatnya Loyalitas Pelanggan sebesar 0,513. Nilai signifikanasi variabel Kepuasan Pelanggan sebesar 0,000 lebih kecil dibandingkan dengan nilai signifikan yang dapat diterima yaitu 0,05 $(\alpha=0,000<0,05)$ sehingga hasil ini mendukung hipotesis kedua bahwa Kepuasan Pelanggan berpengaruh positif terhadap Loyalitas Pelanggan.

Berdasarkan hasil analisis data terkait pengaruh kualitas pelayanan, kepuasan pelanggan terhadap loyalitas pelanggan. Temuan pertama, diketahui bahwa terdapat hubungan kualitas pelayanan terhadap loyalitas pelanggan penggunaan DANA. Hubungan tersebut mempengaruhi peningkatan loyalitas pelanggan dalam menggunakan DANA. Artinya, terdapat pengaruh kualitas pelayanan terhadap loyalitas pelanggan. Jadi, semakin tinggi kualitas pelayanan semakin tinggi loyalitas pelanggan. Ukuran kualitas pelayanan tidak hanya ditentukan oleh pihak yang melayani, tetapi lebih banyak ditentukan oleh pihak yang dilayani. Pelangganlah yang menikmati layanan sehingga dapat mengukur kualitas pelayanan berdasarkan harapan-harapan pelanggan dalam mengukur kualitas pelayanan dalam memenuhi kepuasannya. Temuan penelitian di atas bersesuaian dengan teori bahwa kualitas pelayanan menjadi ukuran harapan pelanggan sehingga mereka dapat terpenuhi kepuasannya (Pramana \& Sukresna, 2016; Situmorang, 2017). Ketika pelanggan percaya bahwa merek lebih dari sekadar sebuah nama, ketika merek menjadi resume yang mencerminkan prestasi, penampilan, dan keunggulan, maka orang akan mengejarnya (Sintya et al., 2018; Yolanda \& Yuniati, 2016). Ada beberapa faktor yang bisa memuaskan pelanggan, di antaranya adalah melalui peningkatan kualitas barang, potongan harga, peningkatan pelayanan, menyentuh unsur emosional (brand), dan kemudahan akses mendapat produk (Sapitri et al., 2020). Temuan ini diperkuat dengan temuan penelitian sebelumnya yang menyatakan bahwa kualitas pelayanan memberikan pengaruh terhadao loyalitas pelanggan (Kadir et al., 2018; Situmorang, 2017).

Temuan kedua, menunjukkan kepuasan pelanggan berpengaruh positif terhadap loyalitas pelanggan. Pada dasarnya tujuan dari suatu usaha adalah untuk menciptakan para pelanggan yang merasa puas. Terciptanya kepuasan pelanggan dapat memberikan beberapa manfaat, diantaranya hubungan antara perusahaan dengan pelanggan menjadi harmonis, memberikan dasar yang baik bagi pembelian ulang dan terciptanya loyalitas pelanggan, serta secara sadar maupun tidak sadar memicu pelanggan untuk ikut mempromosikan ecommerce yang menjadi andalannya dari mulut ke mulut yang menguntungkan perusahaan (Annas et al., 2019; P. S. A. Dewi \& Suprapti, 2018). Kepuasan pelanggan berpengaruh secara signifikan terhadap loyalitas pelanggan (Rafiah, 2019). Hal ini juga didukung oleh temuan penelitian yang menyatakan bahwa kepuasan pelanggan memiliki pengaruh yang signifikan terhadap loyalitas pelanggan (Sari \& Jatra, 2019). Dalam penelitian ini kepuasan pelanggan memiliki peran yang penting dalam memediasi kualitas layanan dengan loyalitas pelanggan. Hasil penelitian ini menunjukkan bahwa pengalaman kepuasan yang dirasakan pelanggan saat menggunakan DANA akan membuat pelanggan kembali menggunakan aplikasi tersebut dilain waktu dan dapat menjadi pelanggan yang loyal. 


\section{Simpulan}

Kualitas pelayanan dapat mempengaruhi loyalitas pelanggan secara positif yang berarti semakin tinggi kualitas pelayanan yang diberikan perusahaan maka semakin tinggi juga loyalitas pelanggan. Hal ini mengindikasikan bahwa ditengah masa physical distancing akibat pandemi COVID19, layanan DANA dapat memberikan pelayanan yang optimal sehingga pelanggan tetap setia menggunakan jasa pembayaran digital yang diselenggarakan oleh DANA. Secara parsial, kepuasan pelanggan menjadi variabel yang memiliki pengaruh dominan terhadap loyalitas pelanggan. Hal ini berarti ditengah masa physical distancing kepuasan pelanggan menjadi hal yang utama perlu diperhatikan oleh perusahaan. Implikasi penelitian ini diharapkan dapat meningkatkan kualitas pelayanan, sehingga dapat meningkatkan loyalitas pelayanan.

\section{Daftar Pustaka}

Anggia, T. R., Kawet, L., \& Ogi, I. (2015). Analisis Pengaruh Strategi Promosi, Harga, dan Kepuasan terhadap Loyalitas Konsumen Surat Kabar Manado Post. Jurnal EMBA, 3(2), 1041-1050. https://doi.org/https://doi.org/10.35794/emba.v3i2.9283.

Annas, A. N., Arifin, R., \& Hufron, M. (2019). Pengaruh Fasilitas dan Lokasi Terhadap Loyalitas Pelanggan Melalui Kepuasan Sebagai Variabel Intervening (Studi Kasus Konsumen Awi Futsal Laok Jang-jang, Sumenep. Jurnal Riset Manajemen, 08(05), 43-61. http://riset.unisma.ac.id/index.php/jrm/article/view/4008/3490.

Bulan, T. (2016). Pengaruh Kualitas Pelayanan dan Harga terhadap Loyalitas Konsumen pada PT. Tiki Jalur Nugraha Ekakurir Agen Kota Langsa. Jurnal Manajemen Dan Keuangan Unsam, 5(2), 592-602. http://jurnal.unsam.ac.id/index.php/jmk/article/view/73.

Chang, T. Y., Hong, G., Paganelli, C., Phantumvanit, P., Chang, W. J., Shieh, Y. S., \& Hsu, M. L. (2020). Innovation of dental education during COVID-19 pandemic. Journal of Dental Sciences, 155. https://doi.org/10.1016/j.jds.2020.07.011.

Darmalaksana, W., Hambali, R. Y. A., Masrur, A., \& Muhlas. (2020). Analisis Pembelajaran Online Masa WFH Pandemic Covid-19 sebagai Tantangan Pemimpin Digital Abad 21. Karya Tulis IImiah (KTI) Masa Work From Home (WFH) Covid-19 UIN Sunan Gunung Djati Bandung Tahun 2020, 1(1), 1-12. http://digilib.uinsgd.ac.id/id/eprint/30434.

Dewi, F. K., \& Ariyanti, M. (2020). Perbandingan User Experience Aplikasi Digital Wallet (Pengguna Go-Pay, OVO, DANA, dan LinkAja) Pada Mahasiswa Bandung. Jurnal Manajemen Teknologi, 19(2), 111-129. https://doi.org/10.12695/jmt.2020.19.2.1.

Dewi, P. S. A., \& Suprapti, N. W. S. (2018). Membangun Loyalitas Pelanggan melalui Kepuasan yang Dipengaruhi oleh Kualitas Produk, Persepsi Harga dan Citra Merek (Studi pada Produk Smartphone Merek Oppo). Matrik : Jurnal Manajemen, Strategi Bisnis Dan Kewirausahaan, 12(Agustus),

87-98. https://doi.org/https://doi.org/10.24843/MATRIK:JMBK.2018.v12.i02.p01.

Haryoko, U. B., Delimah Pasaribu, V. L., \& Ardiyansyah, A. (2020). Pengaruh Harga Dan Kualitas Pelayanan Terhadap Kepuasan Konsumen Pada Firman Dekorasi (Wedding Organizer). Point, 2(1). https://doi.org/10.46918/point.v2i1.566.

Hendriyati, L., \& Santoso, I. B. (2021). Strategi Pemasaran Food and Beverage untuk Meningkatkan Penjualan pada Masa Pandemi Covid-19 di Cavinton Hotel Yogyakarta Indonesia. Journal of Tourism and Economic, 4(1), 60-72. https://doi.org/https://doi.org/10.36594/jtec.v4i1.111.

Ishak. (2017). Analisis Penggunaan Aplikasi Pelaporan Dana. ELKHA : Jurnal Teknik Elektro Untan, 9(2), 36-44. https://doi.org/10.26418/elkha.v9i2.25117.

Jalil, I., Yunus, M., \& Chan, S. . . (2017). Pengaruh Promotion Mix Dan Kualitas Pelayanan Terhadap Customers Trust Serta Dampaknya Pada Loyalitas Pelanggan. Jurnal Ekombis, 4(2), 118-127. https://doi.org/10.35308/ekombis.v3i1.411.

Kadir, A., Basri, M., \& Rodi, R. (2018). Pengaruh Kualitas Pelayanan Terhadap Kepuasan, Nilai, Kepercayaan Dan Loyalitas Pelanggan Rumah Tangga Pada Perusahaan Daerah Air Minum 
Kota Kendari. Journal Publicuho, 1(1), 28. https://doi.org/10.35817/jpu.v1i1.7297.

Mulyati Akib, Ika Maya Sari, A. (2017). Pengaruh tanggung jawab moral dan kualitas pelayanan terhadap kepatuhan pelaporan wajib pajak badan (studi pada kantor pelayanan pajak pratama kendari). Jurnal Akuntansi Dan Keuangan, 2(2), 73-85. https://doi.org/10.33772/jak-uho.v2i2.2981.

Nalini, S. N. L. (2021). Dampak Covid-19 terhadap Usaha Mlkro, Kecil dan Menengah. Jesya (Jurnal Ekonomi \& Ekonomi Syariah), 4(1), 662-669. https://doi.org/10.36778/jesya.v4i1.278

Nuraeni, R., Eldine, A., \& Muniroh, L. (2020). Pengaruh Kualitas Pelayanan Harga Kepuasan Pelanggan Terhadap Loyalitas Pelanggan. Manager: Jurnal IImu Manajemen, 2(4), 487. https://doi.org/10.32832/manager.v2i4.3795.

Nurkholis. (2020). Dampak Pandemi Novel-Corona Virus Disiase (Covid-19) Terhadap Psikologi Dan Pendidikan Serta Kebijakan Pemerintah. Jurnal PGSD, 6(1), 39-49. https://ejournal.umc.ac.id/index.php/JPS.

Pakpahan, A. K. (2020). COVID-19 dan Implikasi Bagi Usaha Mikro, Kecil, dan Menengah. Jurnal Ilmiah Hubungan Internasional, 20(April), 59-64. https://doi.org/10.26593/jihi.v0i0.3870.59-64.

Pebriana, P. H. (2017). Analisis Penggunaan Gadget Terhadap Kemampuan Interaksi Sosial Anak Usia Dini. Jurnal Obsesi: Journal of Early Childhood Education, 1(1). https://doi.org/https://doi.org/10.31004/obsesi.v1i1.26.

Pramana, R. I., \& Sukresna, I. M. (2016). Analisis Pengaruh Kualitas Layanan dan Persepsi atas Harga terhadap Loyalitas Konsumen melalui Kepuasan Konsumen (Studi Kasus Pada Konsumen Bus Pariwisata PO Jaya Indah Semarang). Diponegoro Journal of Management, 5(2), 1-15. https://ejournal3.undip.ac.id/index.php/djom/article/view/13960.

Putri, R. N. (2020). Indonesia dalam Menghadapi Pandemi Covid-19. Jurnal IImiah Universitas Batanghari Jambi, 20(2), 705. https://doi.org/10.33087/jiubj.v20i2.1010.

Rafiah, K. K. (2019). Analisis Pengaruh Kepuasan Pelanggan dan Kepercayaan Pelanggan terhadap Loyalitas Pelanggan dalam Berbelanja melalui E-commerce di Indonesia. Al Tijarah, 5(1), 4656. https://doi.org/10.21111/tijarah.v5i1.3621.

Sapitri, E., Sampurno, S., \& Hayani, I. (2020). Pengaruh Citra Merek dan Kualitas Produk Terhadap Kepuasan dan Loyalitas Pelanggan. Jurnal Mandiri : Ilmu Pengetahuan, Seni, Dan Teknologi, 4(2), 231-240. https://doi.org/10.33753/mandiri.v4i2.150.

Sari, N. M. D. S., \& Jatra, I. M. (2019). Peran Kepuasan Pelanggan Dalam Memediasi Pengaruh Kualitas Produk Terhadap Loyalitas Pelanggan Kfc Di Kota Denpasar. E-Jurnal Manajemen Universitas Udayana, $8(12)$,

7349-7369. https://doi.org/10.24843/ejmunud.2019.v08.i12.p22.

Saripudin, A., Oktriawan, W., \& Kurniasih, N. (2021). Pengaruh Kualitas Pelayanan Terhadap Kepuasan Pelanggan Restoran Saung Manglid. Muttaqien; Indonesian Journal of Multidiciplinary Islamic Studies, 2(01), 48-57. https://doi.org/10.52593/mtq.02.1.03.

Setiawati, R., Utami, S., \& Rochani, S. (2019). Pengaruh Harga Dan Kualitas Pelayanan Terhadap Kepuasan Konsumen Pada Alfamart Jl. Jaksa Agung Suprapto No.11 Mojoroto-Kediri. JIMEK : Jurnal IImiah Mahasiswa Ekonomi, 1(2), 285. https://doi.org/10.30737/jimek.v1i2.316.

Sintya, L. I., Karuntu, M. M., Sam, U., \& Manado, R. (2018). Pengaruh Harga Dan Kualitas Layanan Terhadap Kepuasan Pelanggan Jasa Transportasi Go-Jek Online Pada Mahasiswa Feb Unsrat Manado. Jurnal EMBA: Jurnal Riset Ekonomi, Manajemen, Bisnis Dan Akuntansi, 6(3), 17781787. https://doi.org/10.35794/emba.v6i3.20462.

Sisca Aulia. (2020). Pola Perilaku Konsumen Digital Dalam Memanfaatkan Aplikasi Dompet Digital. Jurnal Komunikasi, 12(2), 311 - 324. https://doi.org/10.24912/jk.v12i2.9829.

Situmorang, R. R. (2017). Pengaruh Bauran Pemasaran dan Kualitas Pelayanan terhadap Loyalitas Pelanggan (Studi pada Hotel Dyan Graha Pekanbaru). Jom Fisip, 4(2), 1-12.

Suwandi, S., Hatta, M., \& Elvantonius, E. (2019). Implementasi Metode Imprest Fund Dalam Aplikasi Sistem Akuntansi Dana Kas Kecil Berbasis Web. Jurnal Soshum Insentif, 2(2), 253-264. https://doi.org/10.36787/jsi.v2i2.162.

Yolanda, A. L., \& Yuniati, T. (2016). Pengaruh Kualitas Produk, Word Of Mouth Dan Kepuasan Layanan 
Terhadap Pembelian Mobil. Jurnal IImu Dan Riset Manajemen (JIRM), 5(12), 1-18. http://jurnalmahasiswa.stiesia.ac.id/index.php/jirm/article/download/1419/1435.

Yulianty, P. D., \& Mauludy, A. (2019). Pengaruh Electronic Word Of Mouth Dan Brand Trust Terhadap Keputusan Pembelian Produk Wardah Varian Bedak (Studi Penelitian Pelanggan Wardah Beauty Konter Majalengka). Jurnal Manajemen Dan Akuntansi, XIV(2), 252-261. 